\title{
DNA Virus
}

National Cancer Institute

\section{Source}

National Cancer Institute. DNA Virus. NCI Thesaurus. Code C14200.

A virus that has DNA as its genetic material and does not use an RNA intermediate during replication. 